\title{
A Review Predictive Mathematical Modeling of Alkali-Silica Reaction in Concrete: evolution, current understanding and the knowledge gaps
}

Uma Revisão dos Modelos Matemáticos Preditivos da Reação Álcali-Sílica em Concrete: evolução, compreensão atual e as lacunas de conhecimento

Una Revisión Matemática Preditiva de La Reacción Alcali-Sílice en el Hormigón: evolución, comprensión actual y lagunas de conocimiento

Received: 08/24/2021 | Reviewed: 08/29/2021 | Accept: 09/03/2021 | Published: 09/06/2021

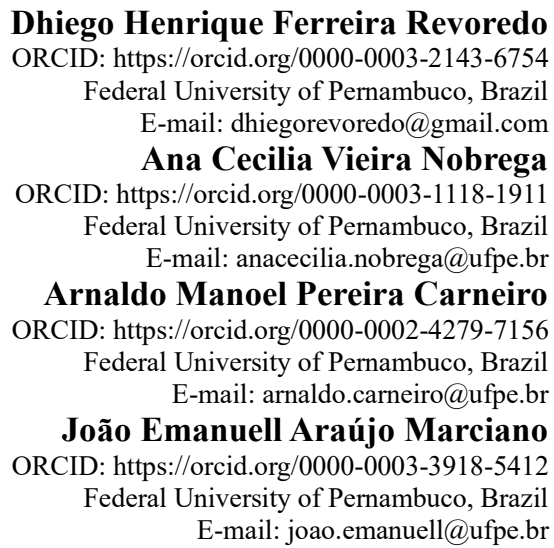

\begin{abstract}
Predictive mathematical models have been proposed in alkali-silica reaction (ASR). Predicting concrete degradation and its effects on mechanical properties is of interest given the long time until degradation becomes critical for intervention and recovery, and difficult structural access for predictive and corrective monitoring and treatment. The present paper presents a general overview of the evolution of the aforementioned predictive mathematical models, interrelating them to the maturation of the phenomenological state of the art associated with ASR. For this purpose, a systematic literature review was used, followed by bibliometric analysis and meta-analysis. In this study, 104 articles from 1974 to 2020 were selected, of which 31 articles were reviewed on the topic of mathematical modeling of ASR. The results of the method indicated the importance of the methodological approach of literature review to provide a comprehensive and chronological view of the evolution of ASR consolidated in the literature. It was found that the mathematical models have evolved considering the phenomenological approach of ASR.
\end{abstract}

Keywords: Alkali-Silica Reaction; Mathematical modeling; Systematic review; Bibliometric analysis; Meta-analysis.

\section{Resumo}

Modelos matemáticos preditivos foram propostos na reação álcalis-sílica (ASR). A previsão da degradação do concreto e seus efeitos sobre as propriedades mecânicas é interessante dado o longo tempo até que a degradação se torne crítica para intervenção e recuperação, bem como o difícil acesso estrutural para monitoramento e tratamento preditivo e corretivo. O presente trabalho apresenta uma visão geral da evolução dos modelos matemáticos preditivos acima mencionados, inter-relacionando-os ao amadurecimento do estado da arte fenomenológico associado ao ASR. Para este fim, foi utilizada uma revisão sistemática da literatura, seguida de análise bibliométrica e meta-análise. Neste estudo, foram selecionados 104 artigos de 1974 a 2020, dos quais 31 artigos foram revisados sobre o tema da modelagem matemática de RAS. Os resultados do método indicaram a importância da abordagem metodológica da revisão bibliográfica ao fornecer uma visão abrangente e cronológica da evolução do RAS consolidada na literatura. Verificouse que os modelos matemáticos evoluíram tendo em conta a abordagem fenomenológica da RAS. Algumas perspectivas futuras de investigação são também sugeridas e discutidas neste artigo.

Palavras-chave: Reação Álcalis-Sílica; Modelagem matemática; Revisão sistemática; Análise bibliométrica; Metaanálise. 


\section{Resumen}

Se han propuesto modelos matemáticos predictivos en la reacción álcali-sílice (ASR). La predicción de la degradación del hormigón y sus efectos en las propiedades mecánicas es de interés dado el largo tiempo que transcurre hasta que la degradación se vuelve crítica para la intervención y la recuperación, así como el difícil acceso estructural para el seguimiento y el tratamiento predictivo y correctivo. El presente trabajo presenta una visión general de la evolución de los modelos matemáticos predictivos mencionados, interrelacionándolos con la maduración del estado del arte fenomenológico asociado a la ASR. Para ello, se utilizó una revisión sistemática de la literatura, seguida de un análisis bibliométrico y un meta-análisis. En este estudio, se seleccionaron 104 artículos desde 1974 hasta 2020, de los cuales se revisaron 31 artículos sobre el tema de la modelización matemática del ASR. Los resultados del método indicaron la importancia del enfoque metodológico de la revisión bibliográfica para proporcionar una visión global y cronológica de la evolución de la ASR consolidada en la literatura. Se comprobó que los modelos matemáticos han evolucionado teniendo en cuenta el enfoque fenomenológico de la ASR. También se sugieren y discuten en este trabajo algunas perspectivas de investigación futuras.

Palabras clave: Reacción Álcali-Sílice; Modelización matemática; Revisión sistemática; Análisis bibliométrico; Metaanálisis.

\section{Introduction}

Eighty years have passed since the first pathological manifestation of alkali-aggregate reaction (AAR) was documented. AAR can occur in three different forms, which are each associated with the type of composite mineral in the reactive aggregate. They are classified as alkali-silicate reaction (ASR), alkali-silica reaction (ASR), and alkali-aggregate reaction (ACR). When classified as ASR, they refer to a reaction between alkali hydroxides ( $\mathrm{k}+$ and $\mathrm{Na}+$ ), from cement clinker and external sources (additions and additives), dispersed in the porous solution in the cement matrix, and amorphous silica, in aggregates.

ASR can occur at random points within the structure, since the siloxane bridges (which form the repeating base of the amorphous silica unit) are sufficiently exposed to alkaline solution. Thus, for the reaction to occur, the siloxane bond is broken by the hydroxyl, and the hydroxyl transforms the siloxane bond into a silanol bond. This reaction forms the hygroscopic alkalisilicone gel, which in presence of moisture expands, and causes stresses in the cement matrix, causing cracking and displacement of the concrete structure.

After the discovery of AAR, numerous researches have been developed to investigate this pathological phenomenon. This reaction is typical of dams, bridges and foundations, it has a slow evolution and a drastic structural degradation, the access and execution of structural recovery is difficult and costly.

With several researches focused on this pathological phenomenon, in several countries, there was in 1974 the first international conference to discuss about alkali-aggregate reaction (ICAAR), in Copenhagen, occurring until today (Swamy, 1992). The ICAAR over the years has gained a strong influence, and from an originally annual event, it has become a highly prestigious quadrennial conference.

In addition to experimental testing, predictive mathematical modeling for ASR has also been a focus of studies aimed at predicting concrete damage (Allahyari et al., 2020). Mathematical models for ASR prediction consider parameters that interfere with this reaction. Due to concrete being the heterogeneous material and its multi-scale interaction nature, several models have been developed and their parameter inputs have been formulated at different scales, nature, vocation and approach.

They have been gradually improved over the years due to new experimental methods. These developments have led to a better phenomenological understanding and their incorporation into the modeling, which has made it possible to link computer programs, both for solving more complex equations and for calibrating the models, which ensures greater accuracy in the results.

Two factors are reported as the most important ASR drivers: a- temperature, for increasing the reaction kinetics (Itam et al., 2019; Larive, 1997; Paulon, 1981) and causing a reduction in gel viscosity, which ultimately makes the gel able to penetrate more easily into concrete pores and cracks (Jones, 1988 apud Pignatelli, 2012); and, b- humidity, both for carrying alkaline cations and hydroxyl ions, and for acting as a gel intumescent agent (Itam et al., 2019). 
Stanton (Stanton, 1940) demonstrated that cements with alkali content lower than $0.6 \%$, the expansion was negligible. Nowadays, this parameter is still considered important to minimize the effects of ASR. Swamy (1991) points out that humidities below $50 \%$ cause almost zero expansion, and start to cause harmful expansions in the concrete structure from $80 \%$. Also according to Itam et al. (2019), a higher relative humidity provides a reduction in the value of the latency time and characteristic time constants. The latency time, or the time to start the reaction is reduced, and consequently, the characteristic time, or the time to start cracking is also reduced. That is, cracking in concrete occurs earlier after the onset of ASR.

These developments have led to better phenomenological understanding and incorporation of the same in the modeling, which has made it possible to link computer programs, both for solving more complex equations and for calibrating the models, which ensures greater accuracy in the results.

This study reviewed the literature on mathematical models of ASR specifically to fulfill the following objectives: a) temporal monitoring of the number of scientific publications in this field; b) literature review to deal with phenomenological aspects and correlate them with mathematical models. These objectives addressed the following questions: (a) "What were the common methods used by authors to develop their research in the domain of ASR in concrete from the phenomenological point of view?", ("b)" What were the mechanisms and operational deficiencies, common, used by authors, to develop their research in the domain of ASR in concrete from the predictive modeling point of view?"; (c) How physicochemical phenomena and microstructural development have been interconnected in both fields of action? ; (d) What is the bibliometric profile (keywords frequently used by authors and journals)?; (e) Who are the top authors in this field?; (f) What are the most important clusters in the research area of predictive modeling for ASR in concrete?; (g) To what extent has research on predictive modeling for ASR in concrete evolved in the last decade?

Of the 31 articles selected from the 104 filtered articles, only five review articles were located addressing more holistically predictive mathematical models for concrete exposed to ASR (Esposito \& Hendriks, 2019; Carles-Gibergues \& Hornain, 2014; Pan et al., 2012; Saouma \& Xi, 2004; Gomes, 2017). In this scenario, this article aims to present the evolution of predictive mathematical models for concrete exposed to ASR, the current understandings, as well as the shortcomings and the contributions of scientific leaps tied to each evolution.

\section{Methodological Aspects of the Research}

The literature review is essential for the development of scientific work. Among the various existing methodologies, the choice of the methodology to be adopted becomes an important criterion to select the most relevant studies for the investigation. Thus, the importance of a more comprehensive investigation on state of the art of mathematical models for AAR was analyzed.

This approach allows analyzing the scenario of publications to: a) avoid duplication of work; b) contribute to the improvement and application of research; c) observe possible flaws in studies; d) evaluate the resources needed to build a study, among other analyses. Although there are few literature review papers on mathematical modeling for ASR, literature review articles are generally among the most sought after by readers of scientific publications (Baek et al., 2018).

Grant and Booth (2009) noted 14 variations of literature review, which can range from an overview to systematic reviews and meta-analyses. However, it is necessary to differentiate between a traditional literature review and a systematic literature review (SLR).

In the traditional review, the researcher gathers information and discusses the set of articles that he or she judges to be important for research. A systematic literature review (SLR), on the other hand, is characterized by an explicit question, defined as a comprehensive and systematic analysis of studies. It is a strategy for screening and including studies, extracting data 
(coding), properly analyzing the data, and then presenting the results (Ravindran \& Shankar, 2015). According to MacLure et al. (2016), the reasons for conducting an RSL are many and varied, in which one can include:

- Identify, evaluate and interpret available research evidence relevant to a specific topic;

- Help inform practice and policy by providing integrated, unbiased evidence on which to base decisions;

- Identify gaps in the literature to inform future studies;

- Minimize trends, using explicit and systematic methods.

Several authors have sought to equate the possible typologies of systematic reviews, due to the existence of several areas of knowledge. Thus, Siddaway, Wood, and Hedges (2018) classify systematic reviews into systematic reviews with metaanalysis; narrative systematic reviews; and systematic reviews with meta-synthesis. For this research, the methodology of systematic reviews with meta-analysis was adopted, which proposes a series of steps (planning; conducting and documenting).

According to Denyer and Tranfield (2009), once the studies related to the research have been collected and evaluated, the process of data analysis will occur, which has the goal of examining the studies individually and understanding how the elements relate to each other. A few of the main methods of analysis are: bibiometric analysis and meta-analysis. Thus, the research consisted of three stages, as per the procedure described below:

1st Stage (Systematic Review): consisted of: a) planning: the need for a SLR was taken into consideration, and after the positive finding, the theme was defined, the databases were chosen, and the search syntax was defined; b) conducting: in this stage the bibliographic search was conducted. The articles found in the databases that fit the research theme were entered into an Excel spreadsheet, and then the selected articles were filtered. After filtering, the inclusion criteria were applied, and finally the articles were selected; c) documentation: the data was synthesized, then the results were systematized, conclusions were drawn, and finally dissemination.

Stage 2 (Bibliometric analysis): this consisted in obtaining the bibliometric graph, generated by the VOSviewer program, from the articles selected in the first stage.

Stage 3 (Meta-analysis): this consisted in carrying out a statistical analysis to obtain the Forest Plot graph. This graph was generated with the help of the Review Manager 5.3 program in the articles selected in the first stage.

Then for the systematic review, bibliometric analysis and meta-analysis of mathematical models for ASR a search was conducted in the Web of Science, Scopus and Engineering Village databases. These were chosen because they are the ones that publish the most scientific technical papers in civil engineering on the subject of RAS. The Booleans used were "alkali silica reaction" AND "model" on July 19, 2020, returning the results as compiled in Table 1, and in Figure 1 illustrated the three stages of the methodological aspect of the research.

Table 1 - Results compiled from articles in each database.

\begin{tabular}{l|c}
\hline \multicolumn{1}{c|}{ Database } & Results (Articles) \\
\hline Web of Science & 66 \\
\hline Engineering Village & 360 \\
\hline Scopus & 312 \\
\hline
\end{tabular}

Source: Authors.

Table 1 showed a large divergence between the publications in the Engineering Village and Scopus databases compared to the Web of Science. Therefore, for research concerning mathematical models for ASR, the Web of Science was incipient. 
Figure 1 - Flowchart of the steps of the systematic literature review.

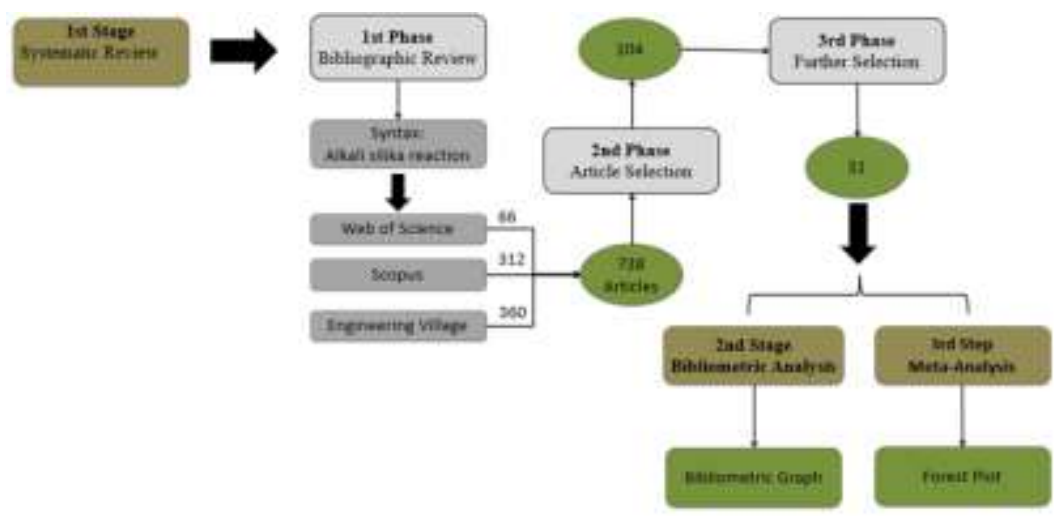

Source: Authors.

Observing Figure 1, the 738 articles were then filtered according to established criteria, for example, repetition of the article in more than one database; year of publication, to determine the chronology of the methods evolution; number of times the article was cited, as it indicates the importance of the research developed on the theme. After filtering, 104 articles were selected.

The 104 selected articles were further analyzed by reading the following items: the title, for being a previous indicator of what will be discussed in the article; the abstract, to better understand the research developed and presented; and, the verification of the bibliographic references, to know which authors make up of the state of the art of the research developed, as well as the frequency of citations that are considered classics in the theme under study. These criteria were adopted to minimize the subjective nature of this selection. Thus, the sample of 104 articles was reduced to a sample of 31 articles, on the subject of mathematical modeling of ASR in the time interval from 1974 to 2020.

In the case of the bibliometric analysis, the criterion "keywords" was adopted and the selected data organized, selected in the VOSviewer (Visualization of Similarities Viewer). Finally, the random effects model was used in the meta-analysis. A study of the quality of the article was performed according to the adopted criteria disassembled in Table 2 and evaluated on a scale as shown in Table 3. With the help of an Excel spreadsheet, the total sum of the scores for the seven criteria was calculated for each article. With this sum (Scri) the mean ( $\mathrm{Scri}=\mathrm{Scri} / 7)$ and the standard deviation (SD) of this mean were calculated.

Table 2 - Evaluation criteria used to analyze the articles.

\begin{tabular}{|c|c|}
\hline Criteria & Description \\
\hline $\begin{array}{l}1^{\circ} \text { Describes the model selection } \\
\text { criteria }\end{array}$ & $\begin{array}{l}\text { Analyze the importance of the proposed mathematical } \\
\text { model. }\end{array}$ \\
\hline $\begin{array}{l}2^{\circ} \text { Identifies factors that influence the } \\
\text { ASR }\end{array}$ & Analyze the importance and evolution of these factors. \\
\hline $\begin{array}{l}3^{\circ} \text { Gathers the necessary data for } \\
\text { understanding the problem }\end{array}$ & $\begin{array}{l}\text { To analyze which authors form the basis of the state of the } \\
\text { art of the research developed. }\end{array}$ \\
\hline $\begin{array}{l}4^{\circ} \text { Presents and defines the adopted } \\
\text { parameters }\end{array}$ & To understand the reason for the use of each parameter. \\
\hline $5^{\circ}$ Explains the modeling procedure & $\begin{array}{l}\text { To verify if it demonstrates the modeling steps for } \\
\text { understanding the phenomenon in question. }\end{array}$ \\
\hline $\begin{array}{l}6^{\circ} \text { Uses graphs and tables for } \\
\text { explanation }\end{array}$ & $\begin{array}{l}\text { To analyze more critically the behavior of the } \\
\text { phenomenon. }\end{array}$ \\
\hline $\begin{array}{l}7^{\circ} \text { Draws coherent conclusions from } \\
\text { the results }\end{array}$ & $\begin{array}{l}\text { To verify the compatibility between results and } \\
\text { conclusions. }\end{array}$ \\
\hline
\end{tabular}

Source: Authors. 
Because of the models' heterogeneity and the difficult comparison between them to compose the meta-analysis, it was proposed for this research to follow a line of qualification of the articles to obtain essential parameters for this analysis. Table 2 shows that the criteria adopted were to reduce the subjectivity of the research and allow a comparison between the models. And in Table 3, the adopted scale is shown, referencing how well the article under analysis corresponded to each criterion.

Table 3 - Description of the quality of the terms.

\begin{tabular}{cl}
\hline Scale & \multicolumn{1}{c}{ Description } \\
\hline 1 & When it does not meet the expectation \\
2 & When it partially meets the expectation \\
3 & When it meets the expectation \\
\hline & Source: Authors.
\end{tabular}

\section{Results}

The results of this research are presented below. The results were divided into three blocks, namely: bibliometric analysis, meta-analysis and systematization of the evolution of mathematical modelling for RSA, according to the topics below.

\subsection{Systematic review analysis}

With the systematization of the articles in the Excel spreadsheet, two analyses can be made. The first refers to the filtering phase in which 104 articles were selected and it was possible to perform a temporal analysis, Graph 1. The second analysis, referring to the selection phase of the articles that were treated in detail, analyzed the most used input data in the models, which were related to properties, physical and chemical composition of concrete, Graph 2.

Graph 1 - Evolution of the number of publications over the years.

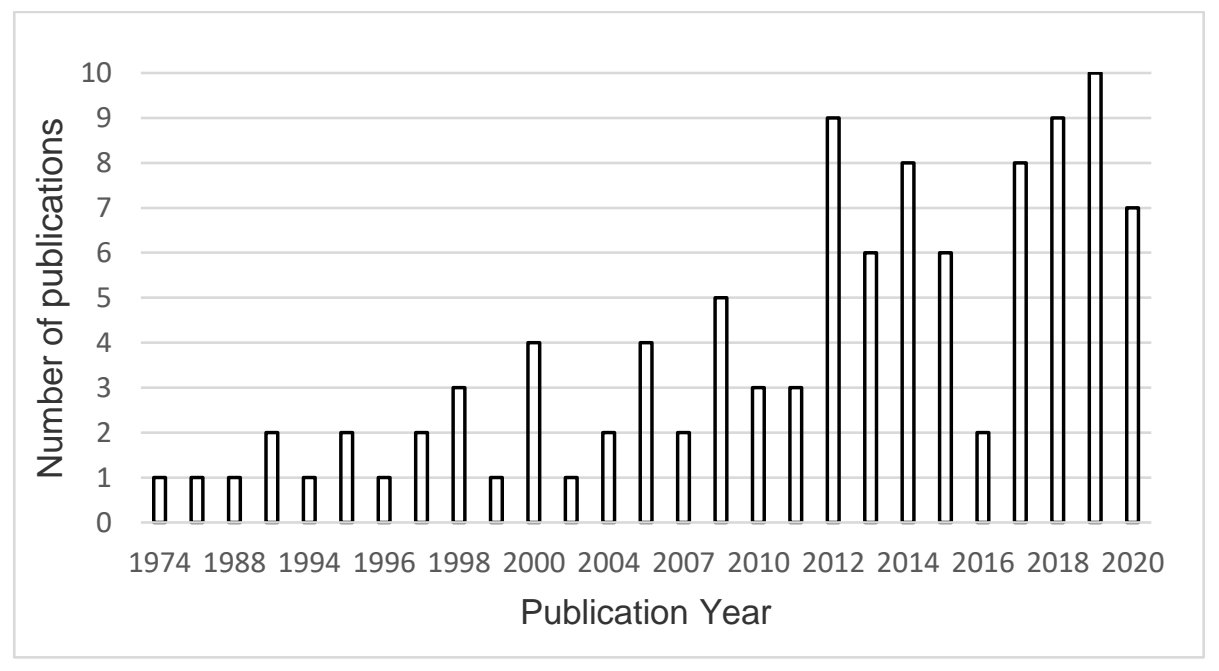

Source: Authors.

It is important to note in Graph 1, that the publications of articles on this subject since the beginning already demonstrated a scientific interest, and that as more conceptions about the pathological phenomenon were obtained, there was great interest in modeling the problem. And in the last decade there has been a significant increase in research on ASR with the aim of predicting, preventing, and ensuring greater durability of structural parts. 
Graph 2 - Most commonly used input data in the models, related to concrete mechanical properties, physical and chemical composition.

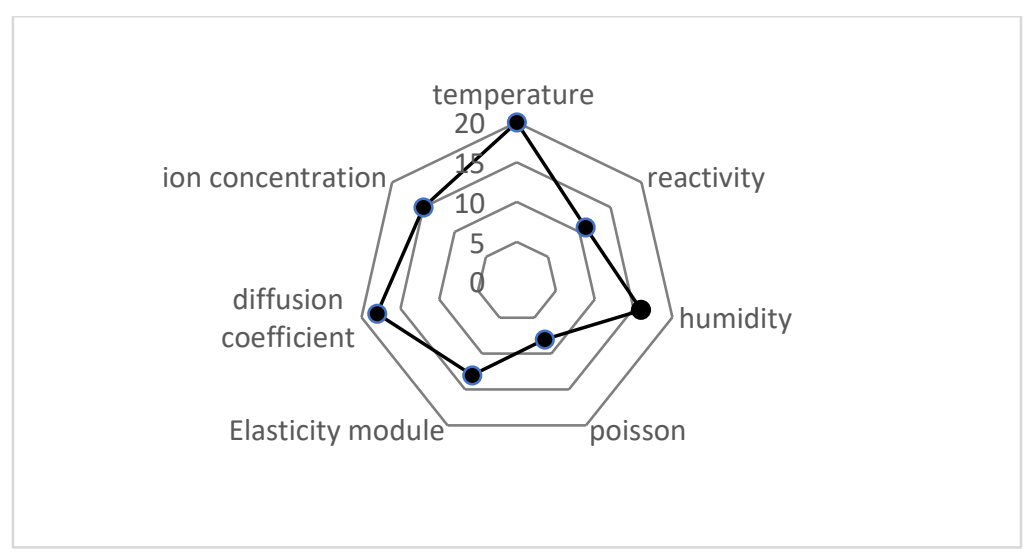

Source: Authors.

From the mathematical models analyzed, it was observed that the most used parameters are compiled in Graph 2. Note that temperature, because it has an influence on the reaction kinetics, is the most adopted, followed by the diffusion coefficient and humidity, which is considered the intumescent agent of the gel. These parameters are mostly used in chemical and chemicalmechanical models. The modulus of elasticity and Poisson coefficient, which characterize the stiffness of the structural part, are adopted in the mechanical and chemical-mechanical models.

\subsection{Bibliometric analysis}

With the data collected and saved in the reading extension, the bibliographical treatment could be carried out, which went through the construction and analysis of networks with the help of VOSviewer as a basis on the 31 articles selected.

The bibliometric graph generated by the keywords criteria is shown in Figure 2. To reduce the number of keywords, a minimum frequency of eight times was requested. In the overall sample, 1,949 keywords were found, 72 of which met the minimum frequency requirement.

Figure 2 - Bibliometric graph of the clustering of journals and magazines publishing on mathematical modeling of concrete ASR.

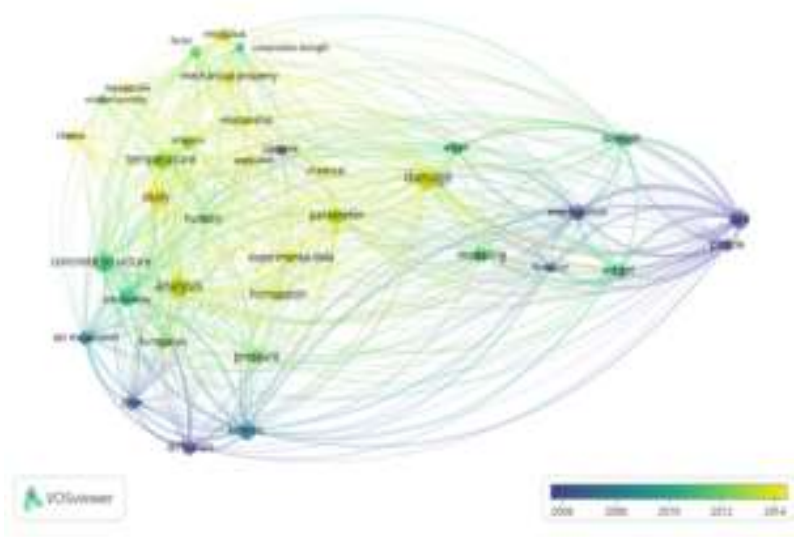

Source: Authors.

Figure 2 shows the characterization of the literature on the SAN. It was convenient to analyze the terms that the 
publications share with each other. In this way, a more relevant approximation of the content of each cluster can be obtained, as well as to complement the clusters already observed in the analysis data. The objective of this criterion is to identify the terms and expressions that are significant in the abstracts, keywords, and titles of the publications.

\subsection{Meta-analysis}

From the meta-analysis, one can analyze the existence of heterogeneity of the published models, and if there is proof of which type of model has better efficiency. Thus, to estimate more precisely the effect size of the 31 selected articles, the Forest Plot graph of Figure 3 was obtained, where the aforementioned articles are classified according to the procedure of calculating the sum of the scores of the 7 criteria, the mean, and the standard deviation described in the methodology.

Figure 3 - Forest plot of the 31 articles in the study in question.

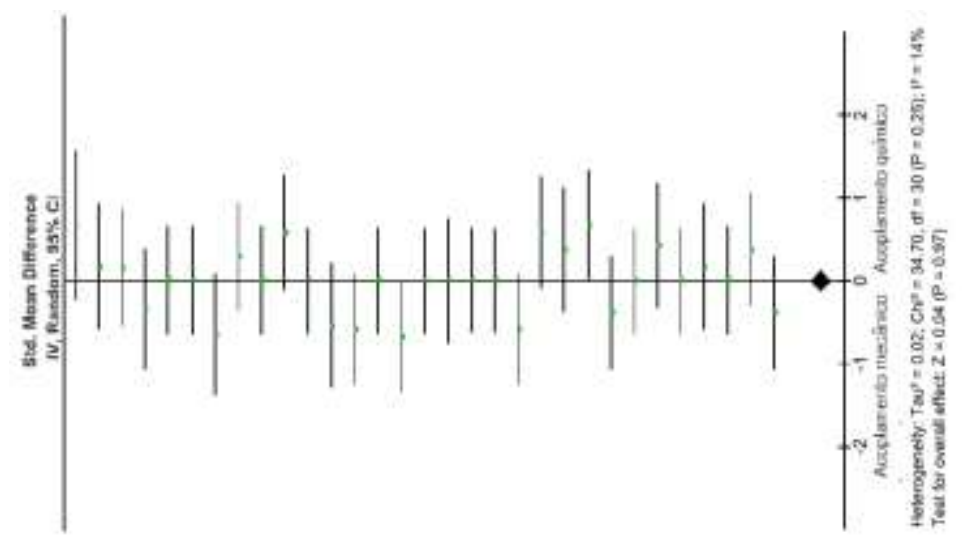

Source: Authors.

From Figure 3, the important thing to note is the result of the meta-analysis that through the data proves that there is no significant difference between the models. Although there is a great heterogeneity in the mathematical models for ASR, they converge to the same result, but with different precision.

\subsection{Systematization of the evolution of mathematical models for ASR}

Figure 4 illustrates a mandala of concentric circular crowns, where evolution of the mathematical ASR models can be seen. The evolution is systematized by the subdivision of the models into: chemical models represented by the smaller crown; mechanical model framed in the central crown, and chemical-mechanical model located in the outer crown; highlighting the increase in the number of approximations along the radius. The heterogeneity of the approximations used in each crown can be observed. The green color highlights the models based on diffusion and reaction coupled to kinetic concepts; the blue color analyzes the production of the formed gel, whose quantification is performed through the gel mass or volume balance; the purple color highlights the models that evaluate the pressure caused by the filling of the concrete pores with the gel, in this approach the porosity becomes an important input parameter and finally the red color evaluates the concrete expansion. 
Figure 4 - Mandala of concentric circular crowns to systematize the evolution of the mathematical models for ASR from the years 1974 to July- 2020.

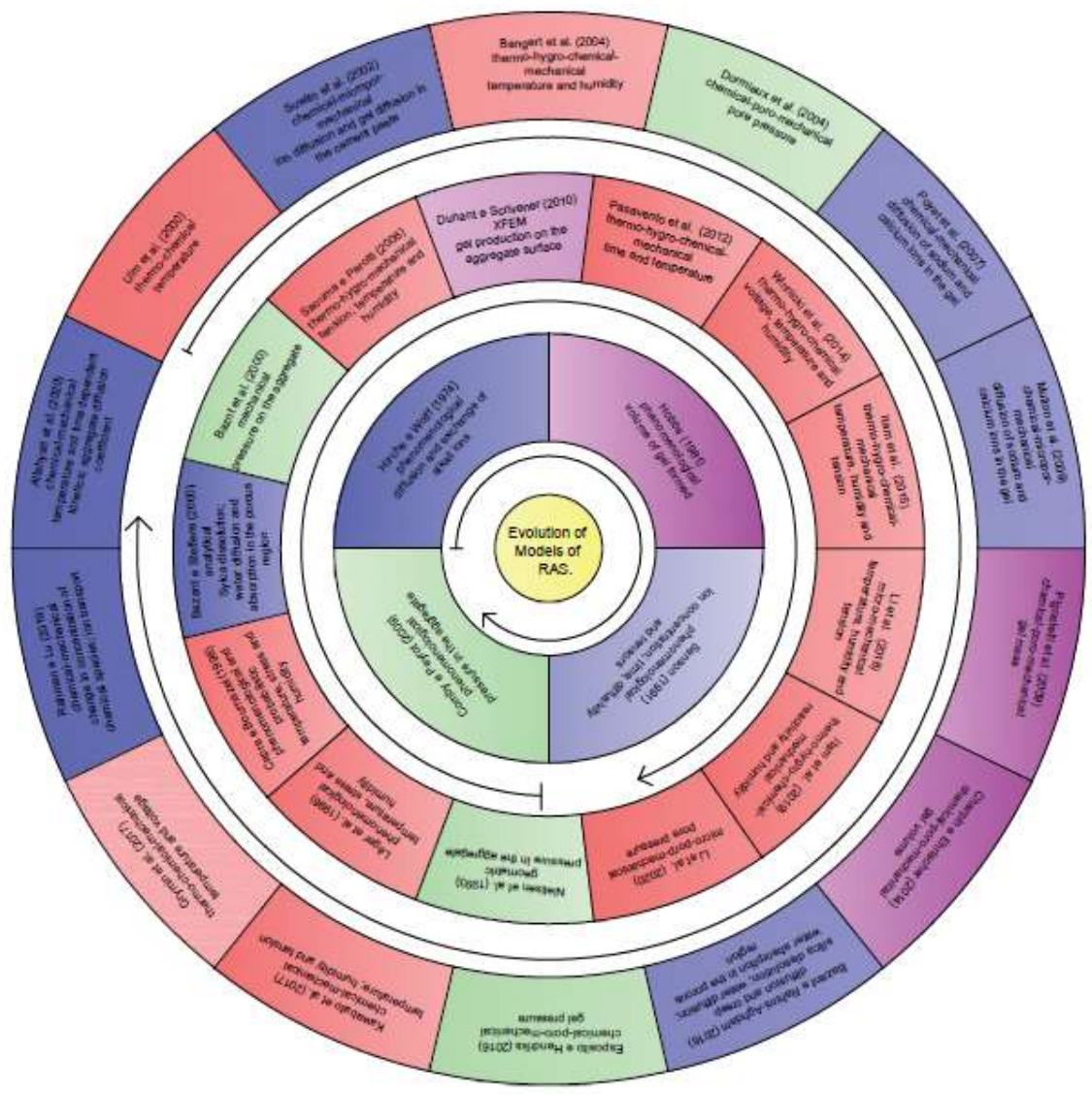

Source: Authors.

With the systematization shown in Figure 4, it is observed that the chemical models were not able to analyze the expansion process. This analysis was possible with mechanical modeling as shown in the central crown of the mandala. The expansion process closed some gaps and made it possible to analyze the structural behavior during the expansion process.

\section{Discussion}

From the results presented above, a discussion will be held regarding each topic addressed.

\subsection{Systematic review}

The 1990s are a landmark of the principal publications on modeling for ASR. Although the reaction is linked to a complex chemistry that makes it difficult to homogenize mathematical models, research has continued to be conducted in search of understanding the mechanisms of ASR, Chart 1 shows this evolution.

From Graph 1 it can see in the selected articles an increasing trend of publication and that, starting in 2012 there was a high rate of publication that has been maintained until the present day. This trend may be correlated with the better comprehension of reaction, increasingly accurate modeling, more robust computer software and the search for increasingly durable structural parts.

When analyzing Graph 2, it is observed that the most used parameter in the models is temperature, as showed in several studies that temperature affects the reaction kinetics and consequently causes an increase in the expansion of concrete (Itam et al., 2019; Larive, 1997; Paulon, 1981). Then there is the diffusion coefficient, moisture, ion concentration, modulus of elasticity, 
aggregate reactivity and Poisson in fewer numbers in the models, but still being necessary parameters for the some of the simulations.

\subsection{Bibliometric analysis}

With the scenario of publications of scientific articles over the years on RSA, it is intended to evaluate the evolution of research and thus contextualize the current stage of the literature on the topic at hand. The objective in this section is to analyze the bibliometric graph, to identify and characterize the main lines of research. Thus, the criterion of clustering by co-occurrence of terms tries by identifying the elements in common in the texts of the selected database, and thus to identify significant terms.

According to Figure 2, based on the bibliometric analysis data, it can be seen that until 2007, corresponding to the purple color, there was a search in understanding the mechanisms of ASR, the impact caused by the gel in the concrete structure, and the factors governing gel formation from a chemical point of view. At that time, the reaction mechanisms were accounted for by the ion diffusion process as discussed by Hirche and Wolf (1974), Svenson (1991), Bazant and Steffens (2000) and Suwito et al. (2002), the time constant and latency characteristic of reaction, and the rate of alkali consumption by kinetic laws.

Although from 1974 to 2007 reaction kinetics had already been introduced to mathematical models for ASR, it was only between 2007 and 2009 (blue color in the graph) that its influences on the gel production rate and the expansion rate were consolidated. From this understanding, the gel production rate and, consequently, the concrete damage process started to be modeled from chemical-mechanical models, as in Poyet et al. (2007), Multon et al. (2009) and Comby-Peyrot et al. (2009).

Between 2009 and 2013, models incorporated phenomenologies on the internal stresses caused by the pressure imposed by the gel to consider gel expansion, crack propagation, and macroscopic expansion, as in Pesavento et al. (2012), Dormieux et al. (2004), Esposito and Hendriks (2016), and Li et al. (2019). Therein, two simplifications were addressed given the phenomenon's complexity: a) the gel pressure as hydraulic pressure in the pores; b) the micro-behavior of the fluid and solid phases as micro-poro-mechanical and chemical-mechanical models.

From 2013 to date, as highlighted in the yellow color of the graph in Figure 3, the chemical-mechanical models have been increasingly consolidated. With technological advances, the models are becoming more and more sophisticated and accurate, taking into account the effect of temperature, humidity, reaction chemistry, and mechanical properties, as in Allahyari et al. (2020), Kawabata et al. (2017), and Grymin et al. (2017).

Table 4 compiles the countries, institutions and authors' profiles of the 31 articles addressing mathematical models of ASR from 1974 to July 2020. 
Table 4 - Countries, institutions, and author profiles of the 31 articles addressing mathematical models of ASR from the years 1974 to July 2020.

\begin{tabular}{|c|c|c|c|c|}
\hline \multirow{2}{*}{ Author } & \multicolumn{4}{|c|}{ General characteristics of publications } \\
\hline & Year & Country & University & Authors' profiles \\
\hline Hirche e Wolff & 1974 & Germany & $\begin{array}{l}\text { Central Institute for Analytical } \\
\text { Chemistry - Research Facility } \\
\text { Nuclear de Jülich }\end{array}$ & \\
\hline Hobbs & 1981 & $\begin{array}{l}\text { United } \\
\text { Kingdom }\end{array}$ & 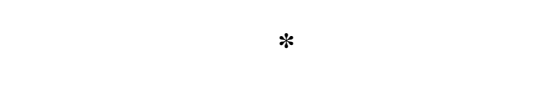 & $*$ \\
\hline Svensson & 1991 & Denmark & * & * \\
\hline Nielsen et al. & 1993 & Denmark & $\begin{array}{l}\text { Technical University of Denmark - } \\
\text { Laboratory for Building Materials }\end{array}$ & Structures \\
\hline Léger et al. & 1996 & Canada & Montreal Polytechnic & $\begin{array}{l}\text { Structures and } \\
\text { Materials }\end{array}$ \\
\hline Capra e Bournazel & 1998 & France & École des Ponts - Navier Lab & Structures \\
\hline Bazant e Steffens & 2000 & USA & Northwestern University & Structures \\
\hline Bazant et al. & 2000 & USA & Northwestern University & Structures \\
\hline Ulm et al. & 2000 & USA & $\begin{array}{l}\text { Institute of Technology of } \\
\text { Massachusetts }\end{array}$ & $\begin{array}{l}\text { Structures and } \\
\text { Materials }\end{array}$ \\
\hline Suwito et al. & 2002 & USA & University of Colorado & Structures \\
\hline Bangert et al. & 2004 & Germany & Structural Mechanics Institute & Structures \\
\hline Dormieux et al. & 2004 & France & École des Ponts et Chaussdes & $\begin{array}{l}\text { Structures and } \\
\text { Materials }\end{array}$ \\
\hline Saouma e Perotti & 2006 & USA & University of Colorado & Structures \\
\hline Poyet et al. & 2007 & France & Nuclear Research Center - Saclay & $\begin{array}{l}\text { Structures and } \\
\text { Materials }\end{array}$ \\
\hline Multon et al. & 2009 & France & University of Toulouse & $\begin{array}{l}\text { Structures and } \\
\text { Materials }\end{array}$ \\
\hline Comby-Peyrot et al. & 2009 & France & École des mines de Paris & Structures \\
\hline Dunant e Scrivener & 2010 & Switzerland & $\begin{array}{l}\text { School of Engineering - Les Labos de } \\
\text { IMX }\end{array}$ & Materials \\
\hline Pesavento et al. & 2012 & Poland & University of Padova & $\begin{array}{l}\text { Structures and } \\
\text { Materials }\end{array}$ \\
\hline Pignatelli et al. & 2013 & Italy & Politecnico di Milano & Structures \\
\hline Charpin e Ehrlacher & 2014 & France & École des Ponts - Navier Lab & Structures \\
\hline Winnicki et al. & 2014 & Poland & $\begin{array}{l}\text { Technical University Tadeusz } \\
\text { Kościuszko }\end{array}$ & $\begin{array}{l}\text { Structures and } \\
\text { Materials }\end{array}$ \\
\hline Itam et al. & 2015 & Malaysia & Universiti Tenaga Nasional & Structures \\
\hline Bazant e Rahimi-Aghdam & 2016 & USA & Northwestern University & Structures \\
\hline Esposito e Hendriks & 2016 & Netherlands & Technical University of Delft & Structures \\
\hline Kawabata et al. & 2017 & France & University Paris-Est & Structures \\
\hline Grymin et al. & 2018 & Poland & Lodz University of Technology & Materials \\
\hline Li et al. & 2019 & China & University Heilongjiang & Materials \\
\hline Itam et al. & 2019 & Malaysia & Universiti Tenaga Nasional & Structures \\
\hline Rahman e Lu & 2019 & USA & Boise State University & Structures \\
\hline Allahyari et al. & 2020 & Australia & University Monash & Structures \\
\hline Li et al. & 2020 & China & College of Harbor & Structures \\
\hline
\end{tabular}

* - Not found. Source: Authors. 
It is noted that France and the USA are the countries that have produced the most research in the area of modeling for ASR, approximately $45.16 \%$ of the articles presented in Table 3 are found in these two countries. These countries stand out due to the numbers of concrete works affected by ASR. In the "Second International Conference on Alkali aggregate Reactions in Hydroelectric Plants and Dams" held in 1995, it was found through publications and reports made by several authors over time, that of the publications on ASR about 50\% of the affected works refer to USA and Canada, and 5\% in France (Priszkulnik, 2005), pointing out that, there has been an increase in the numbers of structures affected by this reaction.

Of the institutions the following stand out: Northwestern University, with three publications, highlighting Bazante and Steffens (2000), Bazante et al. (2000) and Bazant and Raimi-Agdam (2017), authors with high impact publications; École des Ponts, with three publications highlighting Dormiuex (2004), Comby-Peyrot et al. (2009) and Carpin and Erlacher (2014); and, the University of Colorado, with two publications, being Suwito et al. (2002) and Soauma and Perotti (2006).

From the authors' profile it is noted that more than $50 \%$ are structural engineers, being professionals in the area of materials science and engineering only $9.68 \%$ of the evaluated articles, minority in the publications of modeling of RAS in concrete. It is suggested that interdisciplinary collaborative actions between specialists in structures, construction materials, materials science and engineering and chemistry is salutary for the maturation and understanding in the modeling of concrete ASR, contributing to more robust and accurate models.

\subsection{Meta-analysis}

It can be seen in Figure 3 that, for each case study, a comparison between chemical and mechanical modeling was performed. The Forest Plot generated provides the mean difference between groups at a 95\% confidence interval. The rhombus, which is the result of the meta-analysis, has an average difference between studies of $0.00 \%$, so there is no statistical difference between studies, and that the effect size is the same for the compared models. The confidence of the result obtained was given by the inconsistency test $\mathrm{I}^{2}=14 \%$, proving that the systematization of the articles performed in this research was coherent, and considered statistically low, because it is less than the limit of $25 \%$ of inconsistency.

\section{Considerations}

This topic will present a contextualization of the mathematical models for ASR. The analysis consists in verifying the types of approach (chemical, mechanical or chemical-mechanical) and conducting an explanation on the evolution of the models, the failures and the current state in each type of approach, besides including a critical discussion about the different approaches.

\subsection{Research contexts of mathematical ASR models for concrete: chemical, mechanical and chemical-mechanical approaches levels}

Over time, several ASR models have been produced around the world because of the problems caused in the concrete structures. In recent years, several researchers have tried this problem in a more rational way, developing numerical models capable of correlating the effects observed in the structure with the physical-chemical behavior at the material submitted to the alkali-aggregate reaction (Lopes, 2004).

No Brasil, de acordo com Carasek et al. (2016), a produção de modelos matemáticos de RAA ainda se encontra em seus estágios iniciais. Também, diz o autor, para propor um modelo a nível universal no contexto da RAS, este modelo deve descrever a cinética de formação, a expansão do gel e determinar a resposta do concreto a esta expansão. 


\subsubsection{Chemical approaches: evolution, current state and failures}

In the first decades of the discovery of AAR, there was a consensus about a chemical reaction, a consensus that the mechanism governing this reaction is quite complex. In the 1950s and 1960s, studies on the phenomenon lost momentum. Research and testing on the alkali-aggregate reaction returned more rigorously in 1970, when there were more reports of this pathology (Arrais, 2011). With the worldwide problem, there was a need to try to mathematically model the ASR and thus analyze the consequences caused.

From the chemical models, one can notice the interest in the gel and the phenomenology of the reactions for its formation. They would then be then based on diffusion, exchange and concentration in alkali ions to explain the reactions that are then involved in the formation of the ASR gel (Hirche \& Wolff, 1974; Svensson, 1991). In this intercalation, the rate of gel formation was evaluated, through difference in volume of gel formed, and cracking and expansion formation in mortar bars was noted, finding that gel production increases the degree of deterioration (Hobbs, 1981). Finally, the pressure caused by the gel on the aggregate was analyzed (Comby-Peyrot et al..., 2009).

Thus, there was already the sensitivity that there were stresses caused on the concrete matrix as a result of the gel formation with its possible consequences. The first chemical models were efficient to characterize the reaction, but there were gaps regarding the structural behavior. Based on this deficiency, there was an advance in chemical models that increased the ability to evaluate cracking and expansion time, on the basis of the reaction rate considered to be directly proportional to the amount of reacting aggregate, but this advance was restricted to mortar bars (Hobbs, 1981). Chemical models were not able to evaluate; crack propagation; concrete expansion and structural displacement.

\subsubsection{Mechanical approaches: evolution, current status and failures}

As research progressed, there were several theories about the reaction mechanism of this pathology. The theories were usually quite complex and therefore difficult to quantitatively evaluate the phenomenon. Therefore, mechanical modeling was advanced in the context that the consequences of the reaction were of greater interest than the reaction itself.

Thus, in order to develop mechanical models, researchers began to consider the stress exerted by the gel, causing both a cracking in the reactive aggregate and in the surrounding cementitious matrix. Thus, analysis of stresses and strains in concrete structures subjected to ASR (Nielsen et al., 1993), analysis of the aggregate diameter that intensified the reaction (Bazant, 2000) began to consider the pressure generated from the gel as an internal load. With the advance of laboratory techniques, it was possible to analyze analytically the growth of the gel formed and the reaction speed, defined by silica dissolution, diffusion and water absorption (Bazant, 2000).

With the investigations based on the cement-paste-aggregate interaction, it was possible to evaluate the impact of the expansion of the gel in two scales: the mesoscopic scale, which evaluates the stress exerted by the gel on the matrix, and the macroscopic scale, which evaluates the expansion, to account for the effects produced by the ASR on the concrete. From the comprehension of the expansion process, different approaches were developed mainly in massive concrete structures, such as dams, for example.

Although mechanical models have made a great leap in structural calculations, in which there could be a prediction of the internal stresses caused by the gel pressure, and the displacements caused by the production of the gel. It was realized that the concrete deformations induced by ASR could not be modeled by considering an equivalent thermal expansion. Thus, it was recognized that the expansion process depends on the boundary conditions (environmental and material) that were addressed in the chemical models, and the stress state in the concrete.

Thus, phenomenological laws were being adapted to describe the evolution of concrete expansion as a result of temperature, moisture and stress (Comby-Peyrot et al., 2009; Nielsen et al., 1993; Léger et al., 1996), which over time were 
introduced in damage models. Thus, the models obtained a very high amount of parameter inputs, that are not always available for a large amount of concrete mix, environmental conditions and stress state (Esposito \& Hendrik, 2019).

\subsubsection{Chemical-mechanical approaches: evolution, current status and failures}

You can see that models have evolved gradually. With a more refined explanation of the reaction mechanism and its consequences, the models have become more robust. Thus, some models have become outdated, due to changes in the way the reaction is understood today.

Regarding the chemical models, it is observed that they do not address the links between the problems caused by the gel and the structural response (stresses and strains) of the concrete element affected by the RSA. What is noticeable in mechanistic models is the lack of interaction between the chemical and physical processes of the reaction. In other words, the input parameters are modeled mechanically without the chemical input, so that the actions of varying such parameters interfere in the results as expected, but do not guarantee an accuracy close to reality.

The support given to the cause and consequence interaction of ASR came with chemical-mechanical models, where one can first analyze the reaction product at the microscopic level and how its development triggers the mechanical problems, internal stresses at the mesoscopic level and deformations at the macroscopic level. Although this modeling has significantly improved the prediction of the reaction, these modeling does not take into account the randomness of the reaction, i.e., the reaction can occur anywhere in the concrete and start at any face of the reactive aggregate.

\subsubsection{Research contexts of mathematical ASR models for concrete: aggregate and product levels}

Esposito and Hendriks (2019) reported that the mathematical models of ASR can be divided into four types: 1) modeling based on the diffusion mechanism; 2) modeling based on gel production; 3) modeling based on concrete expansion; and, 4) modeling based on internal pressure. The 31 selected articles are compiled in Table 5, duly classified into the four types of modeling mentioned above for concrete under ASR. 
Table 5 - Approaches in the mathematical models of ASR from the years 1974 to July- 2020.

\begin{tabular}{|c|c|c|c|c|c|c|}
\hline Decade & Authors & $\begin{array}{l}\bar{d} \\
\stackrel{d}{\lrcorner}\end{array}$ & 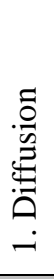 & 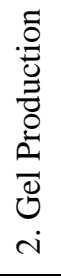 & 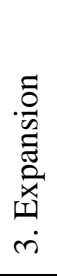 & 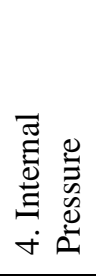 \\
\hline $1970-1980(1)$ & Hirche e Wolf (1974) & Product & & & & \\
\hline $1981-1990(1)$ & Hobbs (1981) & Product & & & & \\
\hline \multirow{7}{*}{$1991-2000(7)$} & Svensson (1991) & Product & & & & \\
\hline & Nielsen et al. (1993) & Aggregate & & & & \\
\hline & Léger et al. (1996) & Aggregate & & & & \\
\hline & Capra e Bournazel (1998) & Aggregate & & & & \\
\hline & Bazant e Steffens (2000) & Product & & & & \\
\hline & Bazant et al. (2000) & Aggregate & & & & \\
\hline & Ulm et al. (2000) & Aggregate & & & & \\
\hline \multirow{8}{*}{$2001-2010(7)$} & Suwito et al. (2002) & Product & & & & \\
\hline & Bangert et al. & Aggregate & & & & \\
\hline & Dormieux et al. (2004) & Aggregate & & & & \\
\hline & Saouma e Perotti (2006) & Aggregate & & & & \\
\hline & Poyet et al. (2007) & Product & & & & \\
\hline & Multon et al. (2009) & Product & & & & \\
\hline & Comby-Peyrot et al. (2009) & Aggregate & & & & \\
\hline & Dunant e Scrivener (2010) & Product & & & & \\
\hline \multirow{14}{*}{$2011-2020(14)$} & Pesavento et al. (2012) & Aggregate & & & & \\
\hline & Pignatelli et al. (2013) & Product & & & & \\
\hline & Charpin e Ehrlacher (2014) & Product & & & & \\
\hline & Winnicki et al. (2014) & Aggregate & & & & \\
\hline & Itam et al. (2015) & Aggregate & & & & \\
\hline & Bazant e Rahimi-Aghdam (2017) & Product & & & & \\
\hline & Esposito e Hendriks (2016) & Aggregate & & & & \\
\hline & Kawabata et al. (2017) & Aggregate & & & & \\
\hline & Grymin et al. (2017) & Aggregate & & & & \\
\hline & Li et al. (2018) & Aggregate & & & & \\
\hline & Rahman e Lu (2019) & Product & & & & \\
\hline & Itam et al. (2019) & Aggregate & & & & \\
\hline & Allahyari et al. & Product & & & & \\
\hline & Li et al. (2020) & Aggregate & & & & \\
\hline
\end{tabular}

Source: Authors.

As for the level shown in Table 5, it refers to the modeling scales, i.e., for product level models, reference to the microscopic scale can be made, referring the aggregate level, that can be subdivided into two scales, which can be the mesoscopic scale, in which the cement paste and aggregate interaction is evaluated, thus assessing the internal stresses caused by gel pressure, and finally the macroscopic scale, which analyzes the concrete through the expansions it undergoes, and consequently the displacements. 
Of the 31 articles under evaluation, nine authors developed mathematical models for ASR based on diffusion mechanisms (Type 1, Table 5); four authors developed mathematical models based on the reaction product, i.e., on gel production (Type 2, Table 5); twelve authors developed mathematical models for ASR based on concrete expansion caused by the gel (Type 3, Table 5); and, finally, six authors developed mathematical models for ASR based on the pressure caused by the gel (Type 4, Table 5).

Furthermore, the temporal evolution suggests that mathematical models have evolved to approaches that are based on expanding concrete under ASR. Of the 14 articles selected for reading in the last decade, eight with mathematical models in this trend stand out. As well as, regarding the level adopted, of the four articles selected, two were diffusion process based, and two were expansion process based.

\subsection{Evolution of mathematical models of ASR for concrete}

Over the years, research has advanced significantly and heterogeneously; that is, in general, each of its models has been development based on the need to understand the reaction system and its deterioration action in concrete (Esposito \& Hendriks, 2019; Carles-Gibergues \& Hornain, 2014; Pan et al., 2012; Saouma \& XI, 2004; Gomes, 2017). The mathematical models were formulated following the schematic characterization shown in Figure 5. This schematization can support in the development of new mathematical models of concrete ASR, and also assist in improving existing models.

It was found that ASR modeling and resulting expansion are necessary to obtain a relevant prediction about the structural response of damaged elements. Thus, the models must take into account chemical and physical aspects to be efficient and reliable (Multon et al., 2009).

As the interaction of internal (chemical composition of concrete) and external (environmental conditions) factors, as well as the difficulty of understanding the reaction mechanism, the modeling of ASR in concrete structures becomes complex (Pignatelli, 2012). In this scenario, the practice of improving existing mathematical models of ASR for concrete is observed.

Figure 5 - Schematic of the mathematical model classifications for ASR.

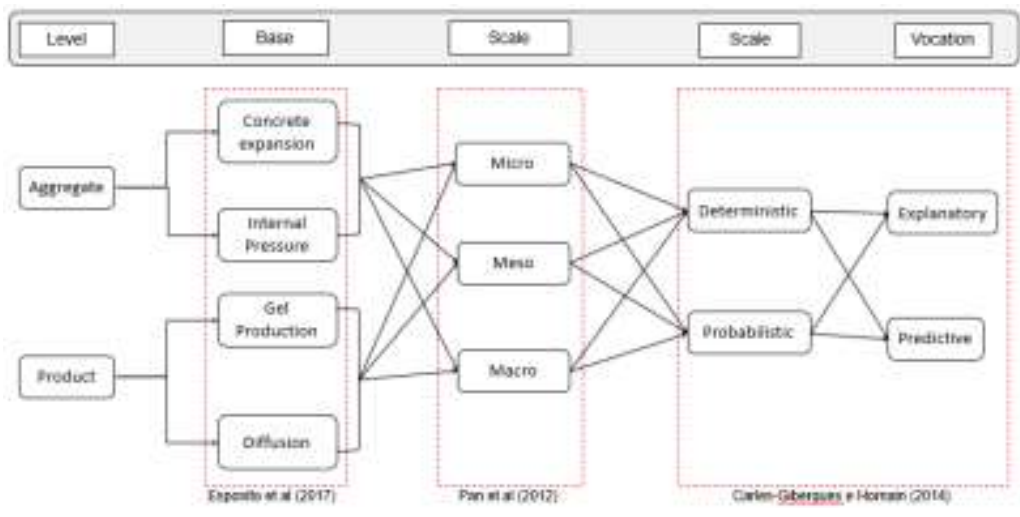

Source: Authors.

From the systematization of the articles, it was possible to draw a flowchart that characterizes a pilot study for the elaboration of future models as shown in Figure 5.

\subsubsection{Evolution of the reliability of ASR models for concrete}

The ability to present a solution to unknown problems, for example, RAS due to its heterogeneous character and difficult accuracy, artificial neural network (ANNs) becomes a promising approach. Research in the field of civil engineering has been 
having results modeled based on ANNs, in which it may become a trend. Work published by Yeh (YEH, 2007) that modeled concrete slump flow and optimized concrete mixtures based on ANN. Olivito (2003) measured deformation in materials using a neural diagnostic system. Allahyari et al. (2020) used RNA to model ASR and compare the results obtained with existing chemical-mechanical models.

Allahyari et al. (2020) used a machine learning approach to achieve a higher degree of confidence in model accuracy or for new model formulations for ASR in concrete. Lee and David Lee (2004) apud Allahyari et al. (2020), say that neurons are highly connected with connection matrices, containing weights and standard deviations. During the learning process, these matrices are updated and adapted to obtain the minimum prediction error (Allahyari et al., 2020). Model validation of Allahyari et al. (2020), was performed by comparison of experimental data. Although the input parameters were affectively and well calibrated and the results were satisfactory, the model became quite complex, making it unattractive for large-scale implementation.

\subsection{Closing the gaps: a roadmap for future research}

With the advances in research, and based on the results and observations, the complexity of the models has increased over the years. The search for more accurate models has become increasingly important worldwide. Thus, it was evaluated the possibility of deepening the theme, in subsequent works:

- Update and complement the information of developed modeling, not computed in this research, in order to obtain a collection of mathematical modeling for AAR;

- Contribute as improvements in the existing models, which did not consider creep, the anisotropy of reaction and expansion, the moisture and temperature variation;

- To take into account in the models the randomness of the reaction, to characterize the initial cracks, the crack distribution and to calculate the crack probability;

- Evaluate experimental programs, which provide input data needed for future models;

- To have a greater interaction in the modeling process between the materials and structures areas; e,

- To cross-reference existing chemical and mechanical models in order to obtain a better refinement in possible chemicalmechanical models.

\section{Conclusion}

It highlights the relevance of the methodological approach of the literature review to provide a comprehensive and chronological perspective of the evolution of ASR consolidated in the literature, which showed the evolution of studies on ASR, from research focusing on the impact caused by gel expansion, to understanding of the chemical reaction in concrete. ASR has been the focus of studies in several countries, with different approaches that cause a great diversity of models. Thus, there is no standardization in the models developed, which hinders the analysis and correlation of the results generated.

From the review and overview of mathematical models, it is possible to analyze the gaps in chemical modeling, and from there, how mechanical models have provided important points in the damage process and mechanical degradation, as well as their shortcomings when considering the final product of the reaction for modeling. Even with ASR investigations evolving, and the models evolving into a mechanical analysis, there were still gaps, due to the modeling being based on the reaction product.

The chemical and mechanical coupling in the models allowed to evaluate the reaction at the microscopic level, and its possible consequences on the concrete structure, at the mesoscopic level, for stress analysis, and at the macroscopic level, for 
expansion analysis. These models have gained robustness due to the sophistication of the mathematics employed and the computational software for analysis. Thus, parametric and analytical models can be modeled in finite element design, as well as in a new design, i.e., ANNs that can represent a solution to complex problems, and may become a new trend.

Although there is a range of mathematical models for ASR, few authors have addressed anisotropy, creep and probability in the models, especially in the chemical-mechanical model. These three concepts are the basis for developing models that make deeper analyses of the phenomenon and more accurately assess degradation of mechanical properties in concrete.

Most input data for the models can be obtained from laboratory tests, but in most papers the obtaining of these data is not clear, making it necessary to analyze other papers, which hinders the dissemination of data in the scientific environment.

\section{Acknowledgments}

Authors are thankful to FACEPE - Fundação de Amparo a Ciência e Tecnologia do Estado de Pernambuco for its financial support to the research.

\section{References}

Allahyari, H., Heidarpour, A., Shayan, A. \& Nguyen, V. P. (2020). A robust time-dependent model of alkali-silica reaction at different temperatures, Cem. Composite Concr. 106, 103460.

Arrais, M. S. M. C. (2011). Reação álcali-silicato: avaliação do comportamento de agregados graúdos da região metropolitana do Recife frente a diferentes tipos de cimento. Universidade Federal de Pernambuco.

ASTM, C. 1260-14. American Society for Testing and Materials, Standard Test Method for Potential Alkali Reactivity of Aggregates (Mortar-Bar Method), Annu. B. ASTM Stand. 4 (n.d.).

Baek, S., Yoon, D. Y., Lim, K. J., Cho, Y. K., Seo, Y. L. \& Yun, E. J. (2018). The most downloaded and most cited articles in radiology journals: a comparative bibliometric analysis. European Radiology, 28, 4832-4838. https://doi.org/10.1007/s00330-018-5423-1

Bangert, F., Kuhl, D. \& Meschke, G. (2004).Chemo-hygro-mechanical modelling and numerical simulation of concrete deterioration caused by alkali-silica reaction. Int. J. Numer. Anal. Methods Geomech. 28..689-714. https://doi.org/10.1002/nag.375.

Bazant, Z.P. \& Rahimi-Aghdam, S. (2017).Diffusion-controlled and creep-mitigated asr damage via microplane model. I: Mass concrete, J. Eng. Mech. 143. https://doi.org/10.1061/(ASCE)EM.1943-7889.0001186.

Bazant, Z. P., Zi, G. \& Meyer, C.(2000). Fracture mechanics of ASR in concretes with waste glass particles of different sizes. J. Eng. Mech. 126. 226-232. https://doi.org/10.1061/(ASCE)0733-9399(2000)126:3(226).

Bazant, Z. P. \& Steffens, A. (2000).Mathematical model for kinetics of alkali-silica reaction in concrete. Cem. Concr. Res. 30. 419-428. https://doi.org/10.1016/S0008-8846(99)00270-7.

Carasek, H., Cascudo, O. \& Gomes, G.C. (2016).Contribuição à previsão de danos para estruturas de concreto atacadas pela reação álcali-agregado. Rev. IBRACON Concreto e Construções. 83. pp.30-38.

Carles-Gibergues, A. \& Hornain, H. (2014). A durabilidade do concreto frente às reações expansivas de origem endógena, Durabilidade Do Concreto Bases Científicas Para a Formulação Concretos Duráveis Acordo Com o Ambient. Tradução Cascudo, O., Carasek, H.

Capra, B. \& Bournazel, J.-P. (1998).Modeling of induced mechanical effects of alkali-aggregate reactions. Cem. Concr. Res. 28. 251-260. https://doi.org/10.1016/S0008-8846(97)00261-5.

Charpin, L. \& Ehrlacher, A. (2014).Microporomechanics study of anisotropy of ASR under loading. Cem. Concr. Res. 63.143-157. https://doi.org/https://doi.org/10.1016/j.cemconres.2014.05.009.

Comby-Peyrot, I., Bernard, F., Bouchard,P.-O., Bay, F. \& Garcia-Diaz, E. (2009).Development and validation of a 3D computational tool to describe concrete behaviour at mesoscale. Application to the alkali-silica reaction. Comput. Mater. Sci. 46. 1163-1177. https://doi.org/10.1016/j.commatsci.2009.06.002.

Denyer, D. \& Tranfield, D. (2009). Producing a systematic review. In D. A. Buchanan \& A. Bryman (Eds.), The SAGE handbook of organizational research methods. 671-689. Sage Publications Ltd.

Dormieux, L., Lemarchand, E., Kondo, D., Fairbairn, E. (2004). Elements of poro-micromechanics applied to concrete. Mater. Struct. Constr. 37. 31-42. https://doi.org/10.1007/bf02481625.

Dunant, C. F. \& Scrivener, K. L. (2010). Micro-mechanical modelling of alkali-silica-reaction-induced degradation using the AMIE framework. Cem. Concr. Res. 40. 517-525. https://doi.org/https://doi.org/10.1016/j.cemconres.2009.07.024.

Esposito, R. \& Hendriks, M. A. N. (2019). Literature review of modelling approaches for ASR in concrete: a new perspective, Eur. J. Environ. Civ. Eng. 13111331. https://doi.org/10.1080/19648189.2017.1347068. 
Esposito, R. \& Hendriks, M. A. N. (2016). A multiscale micromechanical approach to model the deteriorating impact of alkali-silica reaction on concrete. Cem. Concr. Compos. 70. 139-152. https://doi.org/https://doi.org/10.1016/j.cemconcomp.2016.03.017.

Gomes, G. C. (2017). Modelos preditivos de dano aplicados a estruturas de concreto atacadas por reação álcali-sílica: uma revisão sistemática da literatura. Universidade Federal de Goiás.

Grant, M. J.; Booth, A. (2009). A typology of reviews: an analysis of 14 review types and associated methodologies. Health information and libraries journal, 26, 91-108. https://doi.org/10.1111/j.1471-1842.2009.00848.x

Grymin, W., Koniorczyk, M., Pesavento, F. \& Gawin, D. (2017). Numerical Model of the Alkali-silica Reaction Development with External Source of Alkalis. in: Procedia Eng. 509-516. https://doi.org/10.1016/j.proeng.2017.06.244.

Hirche, D. \& Wolff, G. (1974). Diffusion und ionenaustausch bei der alkali-kieselsäurereaktion. Cem. Concr. Res. 4. 609-621. https://doi.org/10.1016/00088846(74)90010-6.

Hobbs, D.W. (1981). Discussion: The alkali-silica reaction-a model for predicting expansion m mortar. Mag. Concr. Res. 33. 208-220.

Itam, Z., Beddu, S., Mohammad, D., Kamal, N. L. M., Razak, N. A. \& Hamid, Z. A. A. (2019). Simulation of alkali-silica reaction model in a concrete gravity dam at the macroscale and mesoscale, in: Mater. Today Proc., 717-726. https://doi.org/10.1016/j.matpr.2019.06.355.

Itam, Z. \& Husain, H. (2015).Modeling of alkali-silica reaction in a two phased material model. J. Teknol. 76. 13-17. https://doi.org/10.11113/jt.v76.5637.

Kawabata, Y., Seignol, J.-F., Martin, R.-P \& Toutlemonde, F. (2017). Macroscopic chemo-mechanical modeling of alkali-silica reaction of concrete under stresses. Constr. Build. Mater. 137. 234-245. https://doi.org/https://doi.org/10.1016/j.conbuildmat.2017.01.090.

Larive, C. (1997). Apports combinés de l'expérimentation et de la modélisation à la compréhension de l'alcali-réaction et de ses effets mécaniques.

Léger, P., Côté, P. \& Tinawi, R. (1996). Finite element analysis of concrete swelling due to alkali-aggregate reactions in dams. Comput. Struct. 60. 601-611. https://doi.org/10.1016/0045-7949(95)00440-8.

Li, S., Deng, Z., Li, C., Chen, D. \& Zhang, Y. (2020). Modeling of flexural strength degradation induced by alkali-silica reaction. Constr. Build. Mater. 234. 117397. https://doi.org/https://doi.org/10.1016/j.conbuildmat.2019.117397.

Li, B., Baingam, L., Kurumisawa, K., Nawa, T. \& XiaoZhou, L. (2018).Micro-mechanical modelling for the prediction of alkali-silica reaction (ASR) expansion: Influence of curing temperature conditions. Constr. Build. Mater. 164. 554-569. https://doi.org/https://doi.org/10.1016/j.conbuildmat.2018.01.007.

Lopes, L. E. (2004). Modelagem Mecânica E Numérica Da Reação Álcali-Agregado Com Aplicação A Barragens De Concreto. Universidade Federal do Rio de Janeiro, Rio de Janeiro.

MacLure, K., Paudyal, V. \& Stewart, D. (2016). Reviewing the literature, how systematic is systematic. International Journal Of Clinical Pharmacy, 1-10. Springer Science and Business Media LLC. http://dx.doi.org/10.1007/s11096-016-0288-3.

Multon, S., Sellier, A. \& Cyr, M. (2009). Chemo-mechanical modeling for prediction of alkali silica reaction (ASR) expansion. Cem. Concr. Res. 39. 490-500. https://doi.org/https://doi.org/10.1016/j.cemconres.2009.03.007.

NBR 15577-3/18: Agregados - Reatividade álcali-agregado. Parte 3: Análise petrográfica para verificação da potencialidade reativa de agregados em presença de álcalis do concreto, (n.d.).

Nielsen, A., Gottfredsen,F. \& Thøgersen, F. (1993). Development of stresses in concrete structures with alkali-silica reactions. Mater. Struct. 26. 152-158. https://doi.org/10.1007/BF02472932.

Olivito, R. S. (2003).A neural diagnostic system for measuring strain in FRP composite materials. Cem. Concr. Compos. 25. 703-709. https://doi.org/https://doi.org/10.1016/S0958-9465(02)00103-8.

Pan, J. W., Feng, Y. T., Wang, J. T., Sun, Q. C., Zhang, C. H. \& Owen, D. R. J. (2012). Modeling of alkali-silica reaction in concrete: A review, Front. Struct. Civ. Eng. 6. 1-18. https://doi.org/10.1007/s11709-012-0141-2.

Paulon, V. A. (1981). Reações álcali-agregado em concreto. Diss. (Mestrado Em Eng. Civil) -Pós-Graduação Em Construção Civil, Esc. Politécnica Da Univ. São Paulo.

Pesavento, F., Gawin, D., Wyrzykowski, M., Schrefler, B. A. \& Simoni, L.(2012). Modeling alkali-silica reaction in non-isothermal, partially saturated cement based materials. Comput. Methods Appl. Mech. Eng. 95-115. https://doi.org/10.1016/j.cma.2012.02.019.

Pignatelli, R., Comi, C., \& Monteiro, P. J. M. (2013). A coupled mechanical and chemical damage model for concrete affected by alkali-silica reaction. Cem. Concr. Res. 53. 196-210. https://doi.org/https://doi.org/10.1016/j.cemconres.2013.06.011.

Pignatelli R. (2012). Modeling of degradation induced by alkali-silica reaction in concrete structures. Politecnico Di Milano.

Poyet, S., Sellier, A., Capra, B., Foray, G., Torrenti, J.-M., Cognon, H. \& Bourdarot, E.(2007). Chemical modelling of Alkali Silica reaction: Influence of the reactive aggregate size distribution. Mater. Struct. Constr. 40. 229-239. https://doi.org/10.1617/s11527-006-9139-3.

Priszkulnik, S. (2005).Inspeção e diagnóstico de estruturas de concreto afetadas pelas reações cimento-agregado. ISAIA, GC (Ed.), Concreto: ensino, pesquisa e realizações, IBRACON. 1017-1071.

Rahman, M. A. \& Lu, Y. (2019).A time-dependent chemo-mechanical analysis of alkali-silica reaction for the disparate geometry of concrete meso-structure. 
Research, Society and Development, v. 10, n. 11, e449101119810, 2021

(CC BY 4.0) | ISSN 2525-3409 | DOI: http://dx.doi.org/10.33448/rsd-v10i11.19810

Constr. Build. Mater. 847-857. https://doi.org/https://doi.org/10.1016/j.conbuildmat.2019.03.025.

Ravindran, V. \& Shankar, S. (2015). Systematic reviews and meta-analysis demystified. Indian Journal Of Rheumatology, 10, 89-94. Medknow. http://dx.doi.org/10.1016/j.injr.2015.04.003.

Saouma, V. \& Perotti, L. (2006).Constitutive model for alkali-aggregate reactions. ACI Mater. J.

Saouma, V. \& Xi, Y. (2004). Literature review of alkali aggregate reactions in concrete dams. Department of Civil, Environmental, Archit. Eng. Univ. Color.

Siddaway, A. P., Wood, A. M. \& HEDGES, L. V. (2018). How to do a systematic review: a best practice guide for conducting and reporting narrative reviews, meta-analyses, and metasyntheses. Annual Review of Psychology, 70, 747-770.https://doi.org/10.1146/annurev-psych-010418-102803

STANTON, T. E. (1940). Expansion of concrete through reaction between cement and aggregate, in: Proc. ASCE, 1781-1811.

Suwito, A., Jin, W., Xi, Y., \& Meyer, C. (2002).A mathematical model for the pessimum size effect of ASR in concrete. Concr. Sci. Eng. $423-34$.

Svensson, S. E. (1991). Eigenstresses generated by diffusion in a spherical particle embedded in an elastic medium. Int. J. Mech. Sci. 33. 211-223. https://doi.org/10.1016/0020-7403(91)90047-7.

Swamy, R. N. (1991). The Alkali-Silica Reaction in Concrete. CRC Press.

Swamy, R. N. (1992). The Alkali-Silica Reaction in Concrete. Blackie ed.

Ulm, F.-J., Coussy, O., Kefei, L. \& Larive, C. (2000). Thermo-chemo-mechanics of ASR expansion in concrete structures. J. Eng. Mech. 126. 233-242. https://doi.org/10.1061/(ASCE)0733-9399(2000)126:3(233).

Valduga, L. (2007).Influência das condições de ensaio da ASTM C 1260 na verificação da reação álcali-agregado. UFRGS.

Winnicki, A., Serega, S. \& Norys, F. (2014).Chemoplastic modelling of alkali-silica reaction (ASR). in: Comput. Model. Concr. Struct. Euro-C 2014 Int. Conf. 765-774.

Yeh, I.-C. (2007).Modeling slump flow of concrete using second-order regressions and artificial neural networks. Cem. Concr. Compos. 29. 474-480. https://doi.org/10.1016/j.cemconcomp.2007.02.001. 